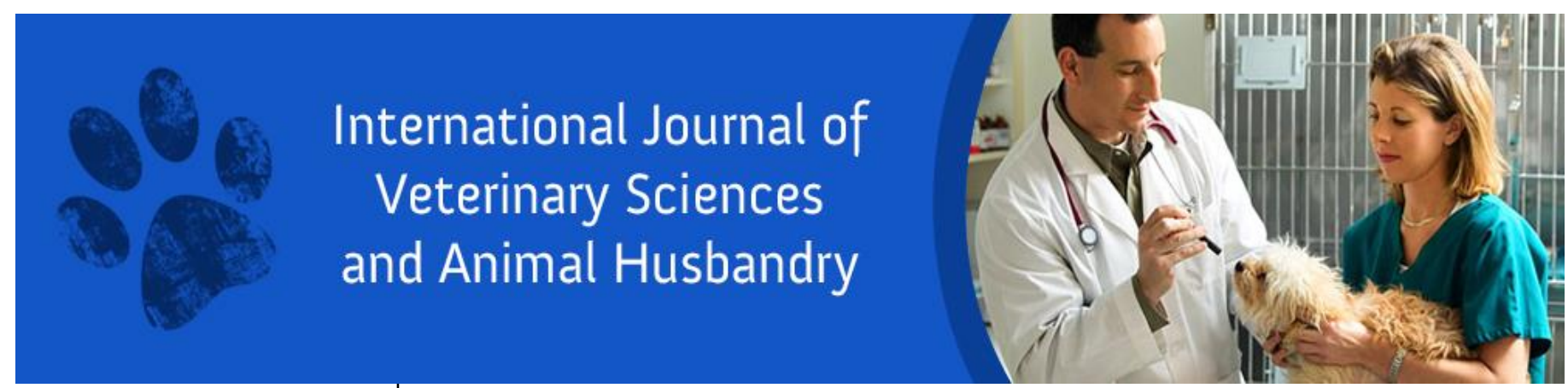

ISSN: 2456-2912

VET 2021; 6(3): 25-29

(C) $2021 \mathrm{VET}$

www.veterinarypaper.com

Received: 16-03-2021

Accepted: 18-04-2021

Dzikri Nurma'rifah Takariyanti Student, Faculty of Veterinary Medicine, Udayana University, Indonesia

I Wayan Gorda

Department of Veterinary

Surgery and Radiology,

Udayana University, Indonesia

Palagan Senopati Sewoyo Student, Faculty of Veterinary Medicine, Udayana University, Indonesia

Corresponding Author:

Palagan Senopati Sewoyo Student, Faculty of Veterinary Medicine, Udayana University, Indonesia

\section{Treatment of transmissible venereal tumor without metastasis in mixed local Balinese dog by surgery and vincristine sulfate: A case report}

\author{
Dzikri Nurma'rifah Takariyanti, I Wayan Gorda and Palagan Senopati \\ Sewoyo
}

DOI: https://doi.org/10.22271/veterinary.2021.v6.i3a.356

\begin{abstract}
A three-year-old mixed local Balinese female dog with 8.8 weight was examined with a mass and swelling in the vaginal area accompanied by blood discharge. Based on histopathological findings, the animal was diagnosed with a transmissible venereal tumor. After physical examination and radiographic evaluation, it can be concluded that there is no metastasis. Treatment is carried out by surgery to excise the tumor mass and followed by chemotherapy using vincristine sulfate at a dose of $0.025 \mathrm{mg} / \mathrm{kg} \mathrm{BW}$ three times at intervals of seven days. Hematological examination before treatment showed lymphocytosis and microcytic hypochromic anemia, and after treatment showed microcytic hypochromic anemia without lymphocytosis. After surgery, the animals were given cefotaxime antibiotic intravenously for two days and continued with cefixime orally for five days. Mefenamic acid analgesia was given for three days orally. On the seventh day after surgery, the wound healed clinically. After two months of follow-up, there were no signs of tumor recurrence. Treatment with surgery and chemotherapy has been shown to be effective in treating TVT case without metastasis.
\end{abstract}

Keywords: dog, transmissible venereal tumor, hematology, surgery, chemotherapy

\section{Introduction}

Venereal sarcoma or generally known as transmissible venereal tumor (TVT) is a malignant tumor that affects the genital organ and is considered highly contagious in dogs. This disease is a serious problem around the world and occurs in the same frequency both male and female dogs who have uncontrolled sexual activity. This tumor has a unique pathogenesis compared to other neoplasms, because the growth is not spontaneous but is transmitted through coitus, (Foster, 2017) ${ }^{[7]}$, licking, and even sniffing (Behera et al., 2012; Foster, 2017; Stockmann et al., 2011) ${ }^{[3,7,16]}$. Dogs of all breeds and ages can be infected, but generally found in dogs with ages ranging from two to five years (Das and Das, 2000) ${ }^{[4]}$. This disease has also been reported in domestic dogs that have not been neutered or spayed (Strakova and Murchison, 2014) ${ }^{[15]}$. TVT cases in Bali are commonly found every year, Dharma et al. (2010) ${ }^{[5]}$ reported that there were 55 cases in the period 2006-2010 which commonly affect roaming local dogs in the streets.

The clinical sign of TVT is a cauliflower-like mass on the genital area or mucosal surface with blood discharge. TVT is classified into two groups based on the location of the tumor mass, genital and extragenital. In genital TVT, the tumor mass is located in posterior area of vagina, especially at vestibulovaginal junction in the female, and located in the caudal aspect of penis and preputium in the male. In extragenital TVT, the tumor mass is located in the outside area of the dog genital, such as in the oral area. This can occur because the dogs are licking or sniffing the genital area (Ganguly et al., 2016).

TVTs cases that are still in the early stages, less than 1-year-old or without metastases, the success rate of treatment with surgery followed by chemotherapy with vincristine sulfate can reach $100 \%$. However, if the case is longer and accompanied by metastases, the success rate of treatment is lower (Marcos et al., 2006) ${ }^{[10]}$. Treatment with surgery and chemotherapy preventing tumor cells from metastasis. 
In this article, the authors report a case of transmissible venereal tumor in female local Balinese dogs treated with surgery and vincristine sulfate.

\section{Case}

\subsection{Signalment and Anamnesis}

A three-year-old mixed local Balinese female dog with a bodyweight of $8.8 \mathrm{~kg}$ was examined at the Department of Veterinary Surgery and Radiology, Animal Teaching Hospital, Udayana University with complaints of a mass in the vagina area and blood discharge since four months ago. Information from the owner stated that initially the mass was small and gradually grew bigger (Fig. 1).

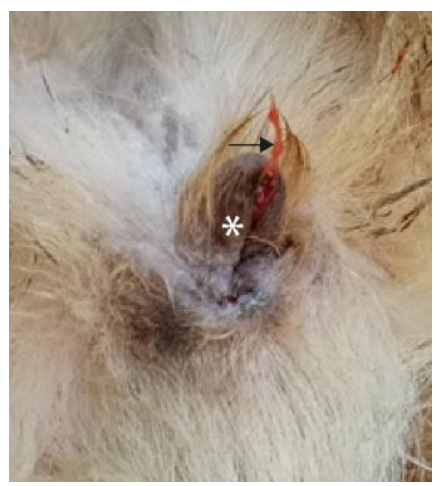

Fig 1: the presence of a tumor mass in the dog's vagina (asterisk) accompanied by blood discharge $(\rightarrow)$

The mass began to appear three weeks after mating with stray dogs. The case dog is kept in the yard and sometimes plays around with other stray dogs. The food provided by the owner with homemade chicken liver twice a day. The dog's behavior is agile and has a good appetite. The dog has a history of rabies vaccinations and deworming.

\subsection{Physical Examination and Clinical Sign}

Table 1: Vital signs on first day of presentation

\begin{tabular}{|c|c|}
\hline Parameter & Value \\
\hline Heart rate & $100 \mathrm{bpm}$ \\
\hline Pulse rate & $100 \mathrm{bpm}$ \\
\hline Respiration rate & 43 breaths per minute \\
\hline Temperature & $38.6^{\circ} \mathrm{C}$ \\
\hline Capillary refill time & 2 seconds \\
\hline Mucosa color & Slightly pale \\
\hline
\end{tabular}

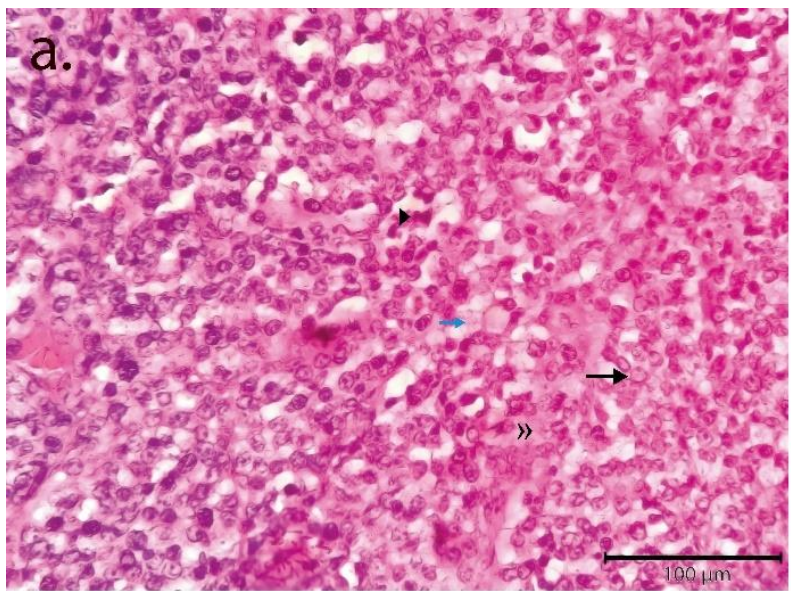

Fig 2: (a) Microscopic features of transmissible venereal sarcoma shown several stroma $(\rightarrow$ ) (b) lymphoblast with homogenous polyhedral shape $(\rightarrow)$. The tumor cells are separated by stroma $(\gg)$. Stroma is composed of fibroblast tissue, extracellular matrix and vasculature $(\rightarrow)$. Several mitotic figures were found ( ) (HE Staining, 100x, 400x) Scale bar: $100 \mu \mathrm{M}$

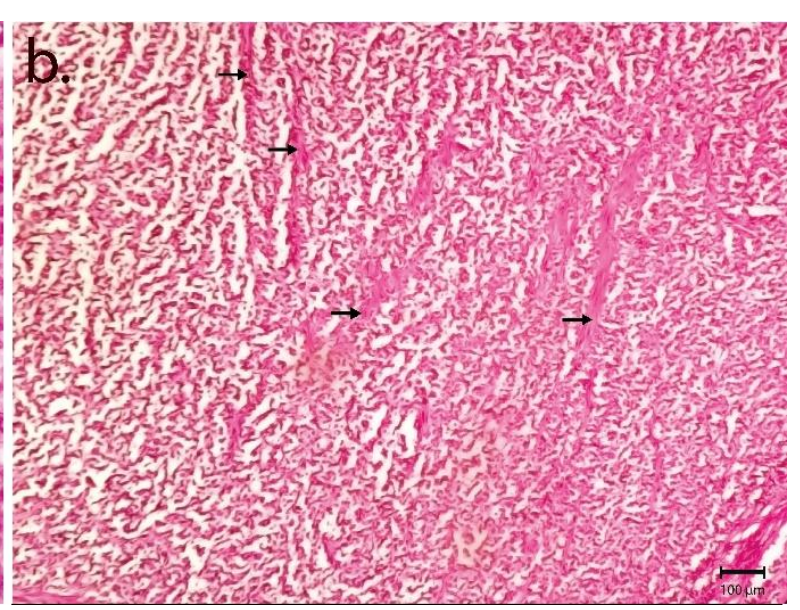

Physical examination showed the dog's present status, presented in Table 1. The obvious clinical signs are swelling in the vaginal area accompanied by blood discharge and when palpated, the mass feels soft with irregular growth. Based on physical examination there is no sign of metastasis.

\subsection{Hematological Examination}

Seven days before surgery, the first hematological examination was carried out. Whole blood was collected in EDTA. The blood was then analyzed in hematological analyzer at Animal Teaching Hospital Faculty of Veterinary Medicine Udayana University. The hematological profile seven days before surgery shows the animal had microcytic hypochromic anemia and leukocytosis (Table 2).

Table 2: Hematological Examination Before Surgery

\begin{tabular}{|c|c|c|c|}
\hline Parameter & $\begin{array}{c}\text { Seven days } \\
\text { before } \\
\text { surgery }\end{array}$ & $\begin{array}{c}\text { Three days } \\
\text { before } \\
\text { surgery }\end{array}$ & $\begin{array}{c}\text { Reference } \\
\text { range }\end{array}$ \\
\hline WBC $\left(10^{3} \mu \mathrm{L}\right)$ & $23.4^{* *}$ & $26.5^{* *}$ & $6.0-17.0$ \\
\hline RBC $\left(10^{6} \mu \mathrm{L}\right)$ & $5.00^{*}$ & $4.84^{*}$ & $5.50-8.50$ \\
\hline HGB $(\mathrm{g} / \mathrm{dL})$ & $7.4^{*}$ & $7.4^{*}$ & $12.0-18.0$ \\
\hline $\mathrm{HCT}(\%)$ & $24.8^{*}$ & $25.3^{*}$ & $37.0-55.0$ \\
\hline $\mathrm{MCV}(\mathrm{fL})$ & $49.7^{*}$ & $52.3^{*}$ & $62.0-72.0$ \\
\hline $\mathrm{MCH}(\mathrm{pg})$ & $14.8^{*}$ & $15.2^{*}$ & $20.0-25.0$ \\
\hline MCHC $(\mathrm{g} / \mathrm{dL})$ & $29.8^{*}$ & $29.2^{*}$ & $30.0-38.0$ \\
\hline Platelet $\left(10^{3} \mu \mathrm{L}\right)$ & 209 & 235 & $200-500$ \\
\hline Plateletcrit $(\%)$ & 0.194 & 0.242 & $0.100-0.500$ \\
\hline
\end{tabular}

Reference range based on Hematological Anaylzer at Animal Teaching Hospital Udayana University. WBC: White blood cells; RBC: Red Blood Cells; HGB: Hemoglobin; HCT: Hematocrit; MCV: Mean Corpuscular Volume; MCH: Mean Corpuscular Hemoglobin; MCHC: Mean Corpuscular Hemoglobin;

$*=$ Lower than reference range, ${ }^{* *}=$ Higher than reference range

\subsection{Radiographic Evaluation}

Radiographic examination was performed to check for the potential for metastasis of TVT in several anatomical sites, but there were no signs of metastases. In this case it was confirmed that this TVT case was not accompanied by metastases.

\subsection{Histopathological Examination}


Confirmation diagnosis is carried out by histopathological examination, sending the biopsy sample to Animal Disease Investigation Center Denpasar Bali. The results of the histopathological examination showed the presence of tumor cells in the form of lymphoblast with homogenous polyhedral shape. The tumor cells are separated by stroma and shows presence of prominent mitotic figures (Figs. 2). Stroma mainly composed by fibroblast, extracellular matrix, and vasculature.

\subsection{Diagnosis and Prognosis}

The final diagnosis is the dog has the transmissible venereal tumor. The prognosis is good because the tumor is still in an early stage and not accompanied with metastasis.

\section{Treatment}

Based on diagnosis and prognosis, the treatment is carried out by surgery to remove the tumor mass, then followed by chemotherapy. Microcytic hypochromic anemia at seven days before surgery is treated by administering Hematodin ${ }^{\circledR}$ (PT. Romindo Primavetcom, Jakarta, Indonesia) intramuscularly for seven days at a dose of $1 \mathrm{~mL} / 5 \mathrm{~kg} \mathrm{BW}$ to stimulate the hematopoietic system. Three days before surgery, a second hematological examination was performed, and the data is presented in Table 2 . The animals had previously been fasted for 12 hours and abstained from drinking for three hours to prevent their vomiting and urination reflexed during surgery. Prior to surgery, animals were premedicated using atropine sulfate (PT. Ethica Industri Pharmaceutical, Bantul, Indonesia) at a dose of $0.02 \mathrm{mg} / \mathrm{kg} \mathrm{BW}$ subcutaneously, then induced with a combination of xylazine (Interchemie, Metalweeg, Netherlands) at a dose of $1.5 \mathrm{mg} / \mathrm{kg} \mathrm{BW}$ and Ketamine (Ket-A-100, Agrovet Market, Lima, Peru) at a dose of $11 \mathrm{mg} / \mathrm{kg} \mathrm{BW}$ intravenously.
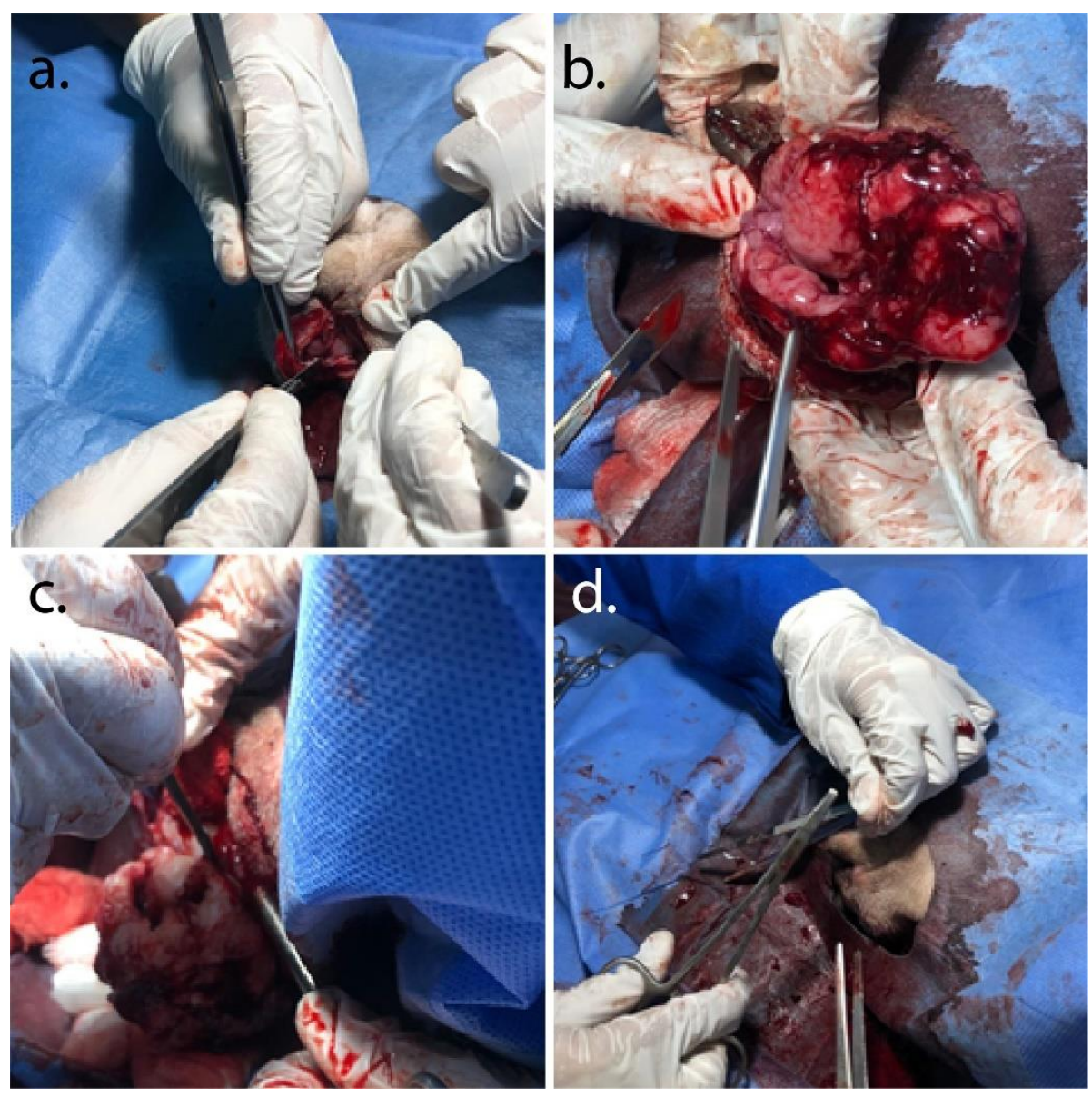

Fig 3: The process of surgery and removal of the tumor mass. (a) Skin incision and excision; (b) the tumor mass is pulled forward. It can be seen that the tumor has cauliflower-like mass (c) tumor and surrounding tissue excision (d) Subcutaneous and skin suture

Surgery is performed with an incision in the vulva dorsally to reveal and find the mass of the tumor. The mass that has been found is then pulled forward and a total excision is started. The entire vagina is cleaned of the tumor mass and the normal tissue where the tumor is attached is excised (Figs. 3). The bleeding that occurs is treated with blood vessel ligation and administration of epinephrine (PT. Ethica Industri Pharmaceutical, Bantul, Indonesia) topically. Excision area then cleaned using $0.9 \% \mathrm{NaCl}$. The subcutaneous tissue was then sutured with a simple continuous pattern using chromic catgut 3.0 and the skin was sutured with a simple interrupted pattern with silk suture materials.
Table 3: Hematological Examination One Week Post-Surgery

\begin{tabular}{|c|c|c|}
\hline Parameter & Value & Reference range \\
\hline $\mathrm{WBC}\left(10^{3} / \mu \mathrm{L}\right)$ & 12.4 & $6.0-17.0$ \\
\hline $\mathrm{RBC}\left(10^{6} / \mu \mathrm{L}\right)$ & 5.74 & $5.50-8.50$ \\
\hline $\mathrm{HGB}(\mathrm{g} / \mathrm{dL})$ & $8.1^{*}$ & $12.0-18.0$ \\
\hline $\mathrm{HCT}(\%)$ & $28.4^{*}$ & $37.0-55.0$ \\
\hline $\mathrm{MCV}(\mathrm{fL})$ & $49.5^{*}$ & $62.0-72.0$ \\
\hline $\mathrm{MCH}(\mathrm{pg})$ & $14.1^{*}$ & $20.0-25.0$ \\
\hline $\mathrm{MCHC}(\mathrm{g} / \mathrm{dL})$ & $28.5^{*}$ & $30.0-38.0$ \\
\hline Platelet $\left(10^{3} / \mu \mathrm{L}\right)$ & 215 & $200-500$ \\
\hline Plateletcrit $(\%)$ & 0.289 & $0.100-0.500$ \\
\hline
\end{tabular}

*=Lower than reference range 
Postoperative animal cases were carried out by cleaning the wound using povidone-iodine and administering antibiotics and analgesics. The antibiotic given was cefotaxime injection (PT. Dankos Farma, Jakarta, Indonesia) at a dose of $22 \mathrm{mg} / \mathrm{kg}$ BW intravenously three times a day for two days followed by administration of cefixime trihydrate antibiotic (PT. Dankos Farma, Jakarta, Indonesia) at a dose of $10 \mathrm{mg} / \mathrm{kg} \mathrm{BW}$ per orally twice a day for five days. The analgesic given was $4 \%$ tolfenamic acid (Vetoquinol, Lure, France) at a dose of 4 $\mathrm{mg} / \mathrm{kg} \mathrm{BW}$ intramuscularly on the first day and followed by administration of $500 \mathrm{mg}$ mefenamic acid (PT. Caprifarmindo Labs, Bandung, Indonesia) at a dose of $25 \mathrm{mg} / \mathrm{kg} \mathrm{BW}$ once a day for two days.

Chemotherapy was carried out three times with intervals of seven days. The first injection was carried out on first day after surgery, then the seventh day, and the last one is on the fourteenth day. Chemotherapy was carried out using vincristine sulfate (PT. Dankos Farma, Jakarta, Indonesia) at a dose of $0.025 \mathrm{mg} / \mathrm{kg} \mathrm{BW}$ intravenously. One-week posttreatment, the hematological profile showed no abnormalities in total leukocytes, but microcytic hypochromic anemia was still present (Table 3). This case dog was then followed up for approximately two months, there were no signs of tumor recurrence. The owner then spays the dog intending to minimize the occurrence of recurring TVT.

\section{Discussion}

Transmissible venereal tumor is an infectious disease in productive young dogs that most commonly occurs in dogs aged two to eight years and there is no breed predisposition and can infect both male and female dogs. According to Boscos et al. (2004), female dogs are more sensitive to this disease than male dogs because one male dog can infect several female dogs. Tumors grow rapidly on the vestibular and vulva in female dogs with a bright red color followed by hemorrhagic discharge.

Surgical treatment accompanied by chemotherapy is considered effective for preventing the tumor from metastasis. Surgery is performed to completely remove the tumor mass and clean the surrounding tissue where the tumor is attached. However, surgical treatment is only performed when the tumor is accessible and not accompanied by metastasis. Surgery is effective if the TVT case is at stage I, the tumor nodule is small, where the tumor is easily accessible, and is non-invasive (Martins et al., 2005) ${ }^{[11]}$. TVT metastases are very rare, and when they do occur they usually affect the regional lymph nodes and surrounding cutaneous tissue (Faccini et al., 2019) ${ }^{[6]}$.

Vincristine sulfate has been used widely as a single chemotherapy agent or combination therapy for the management of TVT cases. Therapy is generally carried out for two to seven weeks intravenously at a dose of 0.025 $\mathrm{mL} / \mathrm{kg} \mathrm{BW}$ depending on the severity of the TVT and the dog's resistance to chemotherapy (Das and Das, 2000) ${ }^{[4]}$. Vincristine sulfate is a chemical compound in the vinca alkaloid class derived from the Catharanthus roseus $L$. alkaloid plant (Ravina, 2011) ${ }^{[13]}$. Vincristine alkaloids have active substances that can inhibit cancer cells. This active substance can stop cancer cell division at the metaphase level, this causes the mitotic process stops at the metaphase stage so the cancer cells experience apoptosis (Avendano and Menendez, 2015) ${ }^{[2]}$.

The results of the first hematological examination, performed a week before the operation showed the dogs had leukocytosis and microcytic hypochromic anemia. This anemia is caused by rupture of the tumor mass so that it sheds blood continuously. Das and Das (2000) ${ }^{[4]}$ stated that the rupture of tumor masses was commonly found in TVT cases so the animal was prone to bleeding. Leukocytosis is common in dogs with TVT (Bahera et al., 2012; Kumar et al., 2018) ${ }^{[3,9]}$. This condition was then treated with Hematodin ${ }^{\circledR}$. After the second hematological examination, three days before surgery, it showed an increase in hematocrit, mean corpuscular hemoglobin $(\mathrm{MCH})$, and mean corpuscular hemoglobin concentration (MCHC) but not significant (Table 2). This is because the blood continues to flow in the dog's vagina.

One-week post-treatment, the hematological profile showed no abnormalities in total leukocytes, but there is a decrease in $\mathrm{Hb}$ and PCV still occurs after treatment is due to the side effects of vincristine sulfate. Vincristine sulfate can suppress bone marrow activity so it directly affects erythropoiesis (Nak et al., 2005; Sandhu and Rampal, 2006) ${ }^{[12,14]}$. While the decrease of leukocytes one-week post-treatment is caused by suppression of progenitor cells in the bone marrow by vincristine sulfate (Nak et al., 2005) ${ }^{[12]}$.

Study by Athar et al. (2001) ${ }^{[1]}$ stated that the treatment of TVTs which begins with surgery only requires 2-3 times of chemotherapy with vincristine sulfate, healing will occur faster and there will be no recurrence. Meanwhile, in the case of transmissible venereal tumors that were only treated with a single vincristine sulfate without surgery, it required repeated chemotherapy up to 5-6 times to clear the tumor mass.

\section{Conclusion}

Surgical management of TVT case without metastasis followed by chemotherapy with vincristine sulfate has a considerable success rate without tumor recurrence.

\section{Suggestion}

Treatment of TVT cases with surgery followed by administration of vincristine sulfate needs to pay attention to the patient's general health condition because of the side effects. as an important note, surgery is only performed in cases of TVT without metastasis. Transmission of TVT in street dogs needs to be minimized by neutering or spaying, so the dog owners who release their dogs do not become infected.

\section{Acknowledgements}

We would like to acknowledge to Dr. I Nyoman Dibia, DVM, M.P. (Pathologist from Animal Disease Investigation Center Bali) for the histopathologic diagnosis of the tumor biopsy sample.

\section{Conflict of Interest}

Author declares that there is no competing interest exist.

\section{References}

1. Athar M, Suhail A, Muhammad G, Shakoor A, Azim F. Clinico-therapeutic studies on canine transmissible venereal tumour. Pakistan Veterinary Journal 2001;21(1):39-43

2. Avendano C, Menendez JC. Anticancer Drugs Targeting Tubulin and Microtubules. In: Medicinal Chemistry of Anticancer Drugs, $2^{\text {nd }}$ Edition, Elsevier Science, Amsterdam, Netherland 2015, 359-390.

3. Behera SK, Kurade NP, Shongsir WM, Durga PD, Krishna KM, Ranjan KM. Clinico-pathological findings in a case of canine cutaneous metastatic transmissible venereal tumour. Veterinarski arhiv 2012;82(4):401-410. 
4. Das U, Das AK. Review of canine transmissible venereal sarcoma. Veterinary Research Communication 2000;24:545-556

5. Dharma DMN, Wirata IK, Supartika IKE. Canine Transmissible Venereal Tumor yang Didiagnosa di Balai Besar Veteriner Denpasar, 2006-2010. Animal Disease Investigation Center Denpasar, Ministry of Agriculture, Indonesia 2010. http://bbvdps.ditjenpkh.pertanian.go.id/wpcontent/uploads/2015/11/PENYEBARANTRANSMISSIBLE-VENEREAL-TUMOR.pdf (accessed 15 April 2021)

6. Faccini LS, Legramanti WM, de Castro LT, Coelho ACB, Teixeria MC, Shild AL et al. Multiple Metastases of a Transmissible Venereal Tumor in a Dog. Acta Scientiae Veterinariae 2019; 47(1):444.

7. Foster RA. Female Reproductive System and Mammae. In: Zachary JF (ed.) Pathologic Basis of Veterinary Disease, Sixth Edition, Elsevier, St. Louis, MO, USA 2017, 1147-1193.

8. Ganguly B, Das U, Das AK. Canine transmissible venereal tumour: A review. Veterinary and Comparative Oncology 2013;14:1-12.

9. Kumar VVVA, Kumari KN, Kumar KS, Kumar V, Lakshman M. Effect of Vincristine chemotherapy in TVT affected dogs. Journal of Pharmaceutical Innovation. 2018;7:163-166.

10. Marcos R, Santos M, Marrinhas C, Rocha E. Cutaneous transmissible venereal tumor without genital involvement in a prepubertal female dog. Veterinary Clinical Pathology 2006;35:106-109.

11. Martins MIM, de Souza FF, Gobello C. The Canine Transmissible Venereal Tumor: Etiology, Pathology, Diagnosis, and Treatment. In: Cocannon W, England G, Verstegen J, Forsberg (Eds.) Recent Advances in Small Animal Reproduction, International Veterinary Information Service, Ithaca, NY 2005, 161-167.

12. Nak D, Nak Y, Cangul IT, Tuna B. A Clinicopathological Study on The Effect of Vincristine on Transmissible Venereal Tumour in Dogs, Journal of the Veterinary Medicine 2005;52:366-370.

13. Ravina E. The evolution of drug discovery: from traditional medicines to modern drugs. Wiley, Weinheim, Germany 2011, 157-159.

14. Sandhu HS, Rampal S. Essentials of Veterinary Pharmacology and Therapeutics, First Edition. Kalyani Publisher, New Delhi, India 2006, 1359-1381.

15. Strakova A, Murchison EP. The Changing Global Distribution and Prevalence of Canine Transmissible Venereal Tumour. BMC Veterinary Research 2014;10:110.

16. Stockmann D, Ferrari HF, Andrade AL, Lopes R, Cardoso, Tereza C, et al. Canine Transmissible Venereal Tumors: Aspects Related to Programmed Cell Death. Brazilian Journal of Veterinary Pathology 2011;4:67-75. 